\title{
Coping with catastrophe: contributing to food security through crop diversity and crop production in Tigray National Regional State in northern Ethiopia
}

R Trevor Wilson ( $\nabla$ trevorbart@aol.com )

\section{Research Article}

Keywords: Genetic resources, Biodiversity, Poverty, Drought, Famine foods

Posted Date: September 30th, 2021

DOI: https://doi.org/10.21203/rs.3.rs-937220/v1

License: (c) (1) This work is licensed under a Creative Commons Attribution 4.0 International License. Read Full License 


\section{Abstract}

Tigray, the most northerly of Ethiopia's ethnic based Regional States, covers an area of $53386 \mathrm{~km}$ sq and has a population exceeding 5.17 million of whom some $24.3 \%$ are urban dwellers. Wide agroclimatic variations result from altitudinal differences (600-3000 + meters) and rainfall patterns. The area is a center of origin of many cultivated and wild plants. The mainly agricultural rural population, farming small areas of non-contiguous plots, makes wide use of these conditions to ensure its livelihood. Crops grown include ten species of cereals, seven pulses legumes), six oilseeds, and numerous fruits, vegetables and spices. Within these groups and species several varieties or landraces are recognized and used to advantage. Wild species are exploited for food, especially at times of crop failure, and for medicines. Crop production is beset by many biotic (weeds, pests, diseases), abiotic (infertile soils) and anthropic (government policy, civil strife, military actions) constraints. Drought is a frequent occurrence and leads to crop failure and famine. In normal times crop yield are low but some of the production is marketed to provide cash for other necessities. Tigray's population is poverty stricken and often in need of food aid.

\section{Introduction}

Tigray National Regional State is the most northerly first-order administrative entity of the Federal Democratic Republic of Ethiopia. The State has an area of $53386 \mathrm{~km}$ sq. In 2016 the human population exceeded 5.17 million of which about $24.3 \%$ lived in urban areas (CSA 2018). Urbanization is proceeding apace as illustrated by the state capital, Mekelle, whose population expanded from about 5000 inhabitants in 1935, to 45000 in 1975, when the current study started, and then to 310000 in 2016 and an estimated 543000 in 2021 (Fig. 1) (UN 2018). More than 97\% of the population is ethnic Tigrayan. Almost $50 \%$ of the population is aged 15 or under.

A traditional ecological classification of the country was brought to the attention of the Western intelligentsia towards the end of the Eighteenth Century (Bruce 1790) and formalized about 100 years later (Dove 1890). The main recognized zones are: kolla comprising the hot lowlands below 1500 meters above sea level with average annual temperatures in excess of $20^{\circ} \mathrm{C}$; the woyna dega at $1500-2500$ meters with temperatures of $16-20^{\circ} \mathrm{C}$; and, the dega or mountainous areas extending up to 3800 meters with temperatures below $16^{\circ} \mathrm{C}$ (Huffnagel 1961). It is to be noted that this traditional classification is temperature-based and takes no account of rainfall which historically has been rather low and in recent years has been subject to recurring droughts (Gebrehiwot Weldegebrial Gebru and Fekedu Beyene 2012).

Such rain that falls is irregular in both time and space. Consequent on thousands of years of cultivation soils are degraded, infertile and highly susceptible to erosion. Various anti-erosion methods have been implemented in recent years leading to some success in slowing run-off and soil loss (Munro et al. 2019). Cultivable land remains, nonetheless, at a premium and the steepest slopes continue to be sown to crops by use of terracing that is maintained by hand labor (Fig. 2). 
Over multiple generations the land has become fragmented. Individual holdings are small and usually comprise several small non-contiguous parcels. Crop yields are low with average household production providing food for only 4.5 months of the year (CSA 2018). Some 1.08 million ha (about $20 \%$ of the land area) is considered suitable for agriculture of which about 1.00 million ha (almost $93 \%$ of potential arable land) is regularly cultivated. About 300000 ha is suitable for irrigation (WFP 2009) but not exploited. The huge domestic animal population greatly exceeds the carrying capacity based on the small amount and poor quality of feed resources. Cattle mostly comprise oxen used for plowing and for transport, but these are productively employed for very few days in the year (Wilson 2003). Continuing degradation of the vegetation is a major problem, much of the original plant cover has disappeared, and remnants remain only in church compounds (Wilson 1977).

Much of the small crop output is lost to pathogens and pests, or by contamination at planting, during growth, at harvesting, and during storage. Weeds are a universal problem. Rodents consume or destroy up to $20 \%$ of the cereal crop in non-outbreak years (Afework Bekele and Leirs 1997). It was already observed in the eighteenth century that "the deficiency of the crop is not from the barrenness of the soils but from the immense quantity of field rats and mice that overrun the whole country and hide in the fissures of the earth" (Bruce 1790). Crops are regularly attacked by passerine birds, notably the red-billed quelea Quelia quelia. In addition to mammals and birds, insects are major pests. The desert locust Schistocerca gregaria and caterpillars of the moth genus Spodoptera, known as army worms, are sporadic in habit but in swarming stages devastate all kinds of vegetation but many insects are cropspecific or limited to a crop group. Shoot flies, stalk borers, midges, crickets and aphids are major pests of cereals (Bijlmakers 1989). Bollworms cause severe losses in cotton. Fungi are a problem on all types of crops and include rusts, smuts, blights, and mildews.

Crops are confronted not only by biological challenges, but also by physical and anthropic ones which, singly and in combination, contribute to catastrophic consequences. Almost 250 years ago, Bruce (1790) wrote "to these plagues may be added still one, the greatest of them all, bad government, which speedily destroys all the advantages they reap from nature, climate and situation". Government, vis-à-vis Tigray, continues to be bad in August 2021, with numerous media reports that Federal troops are preventing farmers from plowing and sowing and destroying crops in situ. The Ethiopian Tewadeho Orthodox Church undoubtedly contributes to poverty and food insecurity, insisting on fasting in order that the faithful shall obtain forgiveness for sins. Fasting, on an average of 180 days a year, is required by all the faithful and includes every Wednesday and Friday. During fasting, all animal products are forbidden, and no food or drink is allowed before noon. No heavy labor (including plowing, harvesting and threshing) is allowed fasting. Lost days of work and near-starvation induced weakness clearly have negative effects on food production.

The specter of drought is never far away. There was severe drought in 1973, since when the country has been depicted as a food deficit country whose people and animals suffer from almost constant drought and famine. Droughts of 12 months duration were recorded in 1983-1985, 1990-1991, 1997-1998, 2002-2005, and 2009-2013 (Amare Sisay Tefera et al. 2019). In January 2002, the over 5 million food 
insecure people had become around 14 million by the end of the year. Drought has another insidious effect as animals die or are sold to raise cash to buy staple foods. The loss of livestock, and particularly draft oxen, results in the enlistment for work of other livestock species unused to and inefficient in the provision of energy for cultivation (Fig. 3).

Cereal and pulse production in 1984/1985 was only $33 \%$ of previous years and only $61 \%$ in $1985 / 1986$. Poor performance was related to drought, a policy of controlling prices and of denying free movement of agricultural products from surplus to deficit areas, the unstable political climate, dislocation of the rural community by resettlement, villagization, and conscription to meet military obligations, land tenure problems, further land fragmentation, failure to distribute farm equipment, and fertilizers, and limited access to extension advice. In response to malnutrition and famine people migrate from rural to urban areas: during the 1983-1985 famine, Mekelle had seven "hunger camps" with 75000 refugees with and a further 20000 people awaiting admittance. In February 2016 approximately 10.22 million people in Ethiopia were listed as "food insecure" (FAO 2016).

The cumulative results of the foregoing biological and non-biological constraints are a pervading poverty and an almost constant state of malnutrition and starvation. Tigrayan farmers attempt to mitigate these problems through their indigenous knowledge and maximum use of the plant genetic resources available to them.

\section{Materials And Methods}

This paper is based on empirical observations, detailed field studies and interviews and discussions with farmers (many of them women), and market buyers and sellers (again, many of them women). During this exercise meetings with administrators, crop scientists, extension workers and key informants and with colleagues on a development study contributed to an understanding of the production, problems and possibilities of the Tigray agricultural environment. An in-depth review of the literature was also undertaken.

\section{The Tigray Agricultural Environment}

From a practical perspective Tigray can be best divided into two major agroecological zones. The one is a lowland plain at 1500-2000 meters altitude in the east which is largely in a rain shadow. The other is an upland plateau and hilly area to the west at 1500-3000 plus meters in altitude. The total rainfall amount is misleading in that it obscures the fact that there are two distinct rainy seasons (CSA 2021) in Tigray, one or other of which, or both, regularly fail. In the meher or main rainy period precipitation falls in June to August and crops are harvested from September to February. Lower rainfall occurs in the belg season of March to May with crops harvested from March to August. Frosts occur at higher altitudes in December through February. Precipitation may occur as hail at any time of year. 
In the lowlands, potential evapotranspiration exceeds rainfall in most years and renders the area marginal for rainfed cropping. Despite this, there is extensive dry land cropping. The main crops are sorghum (mainly Sorghum bicolor although other "sorghums" are grown), tef, and barley. Wheat, maize, linseed, and pulses are minor crops in the lowlands. Sorghum, tef and maize are usually sown in the short rains in April. Tef is harvested in late June whereas sorghum and maize are slower maturing, completing ripening on residual soil moisture and are generally harvested in September or October. Short season barley and wheat is sown during the main rains of July and a second crop of tef may be grown. Chickpeas are sown in late August and mature on soil moisture.

Rainfall is more reliable and more regular in the highlands and is generally in the range $500-1000 \mathrm{~mm}$ per annum. This, and lower temperatures, allows a wider range of crops. Tef and wheat are co-equal main crops. Barley is of considerable importance as are mixed stands of wheat and barley. Various "millets" (Panicum, Eleusine, Digitaria, Setaria species) are grown as is a range of pulses. Linseed is the main oil crop although neug is preferred on black cotton soils. The cropping pattern is not, however, uniform over the highlands and tends to vary with rainfall which is somewhat higher and more regular in the southwest and diminishes and becomes more irregular to the northeast. Thus, some sorghum and maize is grown in the southeast but barley, wheat, tef and finger millet dominate the north. Similarly, linseed is more common in the south whereas neug is more common in the north.

\section{Crop Diversity And Production}

\subsection{Overview}

In 1920, Vavilov postulated that the region of greatest diversity of a plant species is its center of origin (Vavilov 1935; 1951). Ethiopia is the center of origin of at least 38 plants. Tigrayan farmers maximize this natural capital, cultivating at least ten species (one not indigenous) of cereals, seven pulses, six oilseeds, and numerous fruits and vegetables and spices (Table 1). Several crops can be classified under two or more main groups where different parts of the plant have different uses.

Farmers plant different crops to ensure there will be something to harvest and help to stabilize production, to reduce the risk of total crop failure, to mitigate insect and disease damage, and to use labor more efficiently. If all household needs are fulfilled (and even if they are not) there will be some sales at local markets.

\subsection{Cereals}

Estimates of the number of households growing cereals in 2019/2020 were 1.24 million, the area cultivated being 779519 ha at 0.63 ha per household and a total production of 1860528 tonnes, equivalent to 2.39 tonnes/ha (Table 2). Cereals (Fig. 4) are by far the major crop grown for food and occupy as much as $90 \%$ of the cultivated area and are grown by more than $90 \%$ of farm households in both the highlands and lowlands. Cereals account for more than $60 \%$ of rural employment and provide more than $60 \%$ of total caloric intake. They mainly provide staple foods, but some species are used in 
brewing alcoholic beverages and preparing specialty ethnic foods (Nigussie Seboka Tadesse et al. 2020). Approximately $45 \%$ of production is consumed by the household, the remainder being saved for seed, sold, fed to livestock, or to pay hired labor. Oats, Avena spp., are not a crop in Tigray but are a common weed, especially in wheat, at 2200-2800 meters altitude (Ladizinsky 1975).

\subsubsection{Tef}

Tef, both white and red varieties, is the iconic and preferred Tigrayan cereal for making the traditional unleavened bread njera (njera is Amharic, the Tigrinya name being taita although the Amharic designation is commonly used throughout Tigray). Tef has an extremely small gluten free grain. It is used mainly by the household thus it is expensive and sometimes elusive in markets. The flour is often mixed with other cereal flours that may also be used alone. The spongy bread -- smooth below and bubbly above is made from a slightly fermented batter baked on a large round surface - is the basis of many meals. Tef is a preferred crop in other ways as it can be sown later than other cereals and different varieties are grown at different altitudes. The straw is fed to livestock or used as binding in the mud plaster of house walls. Mineral fertilizer and insecticides are occasionally applied. A Bush Cricket and the Black Tef Beetle are major insect pests.

\subsubsection{Wheat}

The area cultivated to wheat in Tigray in 2019/2020 was the third largest cereal crop after sorghum and tef. The three species grown in Tigray are planted over approximately the same area as tef. Durum wheat Triticum durum is the most widespread and its genetic and morphologic diversities are widely exploited (Lijalem Gebrewahid et al. 2021) although the traditional shahan variety is often preferred. The flour is mainly made into ambasha or dabo which is a round, somewhat flattened, leavened bread, but, in part as a relic of the Italian occupation of the 1930s, there is some small scale commercial production of pasta.

Common wheat Triticum aestivum is the most widely grown cereal in the world. It has never been quite so common as durum in Ethiopia, but consequent on varietal improvement and extension pressure it has become more popular throughout most of the country. A variety released in 2011 by the Mekelle Agricultural Research Centre, suitable to rainfall of 300-500 mm at altitudes of 2000-2500 m and maturing in 90-95 days was a semi-dwarf type with good resistance to water stress (Hintsa Gebru et al. 2011): in 2018 discussions with farmers showed that they were largely unaware of this cultivar.

Emmer wheat T. turgidum, sometimes known as hulled wheat, is an awned relict type in most areas but is still popular in Tigray. Emmer, introduced to Ethiopia about 5000 years ago, has cultural and sociological importance, and occupies $7-10 \%$ of the total area of the wheat crop (D'Andrea and Mitiku Haile 2002). Because the grain is hulled, threshing is a heavy and labor intensive process invariably undertaken by women, but this is considered worthwhile due to the taste and texture of the grain's processed products. This traditional plant is lauded as being good for lactating mothers and farmers believe that it helps to set broken bones (Bethlehem Melese et al. 2019). 
Purple grains, caused by anthocyanins in the pericarp, occur in tetraploid wheats from Ethiopia (whence they were first introduced to Europe in the early twentieth century): anthocyanins have potential health benefits as antioxidants (Zeven 1991). Stem borers, shoot flies and aphids are important insect pests (Abebaw Dessie. 2018). Rusts are a major fungal problem of wheat in Tigray (Tesfay Gebrekirstos Gebremariam et al. 2016). Local wheat varieties vary in their susceptibility to rust but as the fungus is so labile new varieties very quickly become infected. A recent study found ergot Claviceps purpurea, which has caused outbreaks of human ergotism over the years, is present in Ethiopia only on wild oats Avena abyssinica at altitudes of 2300-3000 m (Dawit Abate 2017). (Ergot is known to infect other cereals including wheat and barley: the Author of this paper identified typical sclerotia of ergot on a wheat crop near Mekelle in 1974.) As a major staple wheat benefits more than most other crops from mineral fertilization and insecticide application and occasionally from the use of fungicides.

\subsubsection{Barley}

Barley was fifth in the area of cereals cultivated in Tigray in 2019/2020. Ethiopian barley is mainly a 2row type, which is preferred for its low protein and better malting qualities and may account for it not receiving much fertilizer. Cultivation over millennia has resulted in development of many ecotypes including burguda and saessea (D'Andrea and Mitiku Haile 2002). At least 15 landraces are recognized by farmers based on quantitative and qualitative traits (Hailemichael Shewayrga and Sopade 2011). The higher elevations and impoverished soils of Tigray are ideal for barley production. Barley is highly nutritious and is the basic ingredient in many solid and liquid foods. It is important in the socioeconomic and cultural life of Ethiopians (Jemal Mohammed et al. 2016). Roasted whole grain, raw and roasted milled grain, and cracked grain are used in main, side, ceremonial, and restorative dishes. An important use is providing the substrate for brewing tella (siwa in Tigrinya but the Amharic appellation is in common use). Tella is the commonest of several traditional alcoholic drinks, is mildly acidic in taste and contains 2-6\% per cent, and occasionally up to 7\%, alcohol (Mooha Lee et al. 2015).

Barley shoot flies and aphids are the main insect pests. Fungal infections include scald, net blotch, rusts, smuts. mildews, wilts, and blights. Barley yellow dwarf virus (BYDB), transmitted by aphids is widespread in all cereal crops and can reduce yields by as much as $50 \%$ (Jansen 1981). Fertilizers and crop protection products are rarely applied to barley in Tigray.

\subsubsection{Finger Millet}

Finger millet occupied fourth position in area among cereals cultivated in Tigray in 2019/2020. Its adaptability in a wide range of environments with minimal input, a short growing season, tolerance of acid soils, tolerance of drought, and overall production on marginal land where other crops fail, means it is a critical all-round crop for food security and human welfare. The high calcium content makes it important as a food for children, and for pregnant and lactating women (Hailu Feyis Tasisa1et al. 2021). Local farmers carry out pre- and post- harvest selection and have knowledge of at

least 37 landraces or varieties (Yemane Tsehaye et al. 2006). 


\subsubsection{Sorghum}

Sorghum is the most widespread cereal in Tigray, grown mostly in the lowlands and the southwest highlands. Sorghum is the principal food crop in the lowland area of eastern Tigray and in the neighboring Afar Region, not only of farmers but also of families that are mainly livestock owners rather than cultivators. Ethiopia is a center of origin for sorghum (Firew Mekbib 2008). At least 60 landraces are recognized, in part based on farmers' knowledge of performance during storage (Awegechew Teshome et al. 1997; 1999). Farmers also grow several varieties at the same time to reduce risk, and select in particular on time to maturity, short season varieties (60-75 days) being preferred if there is a perception of a poor rainy season and long season ones (90-120 days) if conditions are considered to be better (Nega Gebreselassie Wubeneh and Sanders 2006). It is used to make bread as well as its main culinary use as a stiff porridge. Haulms are fed to livestock and provide structural and roofing materials for houses and fences.

A major production constraint is the obligate root parasitic witch weed, Striga hermonthica, which can reduce yields by up to $70 \%$ or even destroy the plant altogether. Sorghum, however, is prey to a broad range of insect and fungal pests. Insects include stalk borer, shootfly, midge, and rice weevil during storage. Among fungi are anthracnose, grain mold, gray leaf spot, rust, smut, ergot (Claviceps sorghi, also known as Sphacelia sorghi), downy mildew, and leaf blight.

\subsubsection{Maize}

Maize occupied the smallest area of Tigray's cereal crops in 2019/2020. Maize arrived in Ethiopia in the late seventeenth century and was mainly grown as a subsistence crop in the mid-altitudes (1500-2000 meters) in the south of the country ((Huffnagel 1961). The production system up to the 1970s was truly subsistence, yields barely exceeding 1 tonne/ha. Maize in Tigray is produced mainly in the northwest lowlands and in the center of the region where climate and soils are more suited to it. Maize was a little known crop in Tigray before the drought and famine of 1984-1985 but became popularized through free distribution of seeds and as a byproduct of famine relief operations. Early nondescript varieties have recently been largely replaced by higher producing ones.

Much of the crop is sold green on the cob in local markets or as slightly more mature cobs which are eaten roasted. Mature seed is also sold or roasted at home and converted into porridge. The haulm, as for sorghum, is used as animal feed and as a building material.

Maize output is reduced by a plethora of pests and diseases. Stalk borers, termites, weevils and the large grain borer are common insect pests. Leaf blight, gray leaf spot, and common leaf rust are fungal pathogens. Enormous damage is caused by Maize Streak Virus (MSV) and Maize Lethal Necrosis Disease (MLND).

\subsection{Pulses}


Pulse crops (Fig. 5), grown more extensively in Tigray than in most other parts of the country are cultivated from sea level to 3000 meters. The total pulse area in 2019/2020 at 46577 ha was, nonetheless, only $5.9 \%$ of the area of cereals. Pulses were grown by 405006 household, on an average area of 0.12 ha, producing a total yield of 70216 tonnes equivalent to 1.51 tonnes/ha (CSA 2021). Pulses are eaten boiled or roasted or as an ingredient in a stewed dish known as wot, that is often a main plate or taken as a secondary food. Pulses are the most important element in the national diet after cereals and are the main protein source for most people. They are especially important on fasting days when meat is forbidden and misir wot (lentil, kik wot (pea), or shiro wot (bean and chickpeas) are substituted for meat stews.

Horse, field or faba beans occupied just over $25 \%$ of the area sown to pulses in 2019/2020. Beans are critical to household nutrition as they are high in protein and contribute to a diversified diet. In the field, the crop improves soil fertility through nitrogen fixation and helps to reduce pest and weed infestation. Landrace varieties are, however, extremely susceptible to broomrape, a root parasite that regularly reduces crop yields by up to $80 \%$. Broomrape (Orobanche crenata) is widespread in Ethiopia, is continuing to spread very rapidly, and afflicts all pulse species. Conventional control methods are ineffective so the approach is to breed resistant or tolerant varieties and attempt to persuade farmers to exchange these for their own native types (Birhanu Amare and Tsehaye Birhane 2020). Other economically important diseases of beans (and of other pulses) are chocolate spot, bean rust, aschochyta blight, black root rot and various viruses and nematodes (Addis Tegegn et al. 2019).

Field peas were the second most popular pulse grown in $2019 / 2020$, occupying $16.6 \%$ of the pulse area. Uses for food and in the farming system are similar to those of field beans. There is great genetic diversity in field peas in Ethiopia which is made good use of by local farmers (Gemechu Keneni et al. 2005).

A little known subspecies of $P$. sativum restricted to the highlands of South Tigray and North Wello (and to Southern Yemen) is $P$. s. abyssinicum, known in Tigrinya as dekoko (= minute seeded). It differs from the standard pea in having leaves with serrated edges (Haddis Yirga and Dargie Tsegay. 2013). This subspecies exhibits high genetic diversity related mainly to altitude, is considered a highly nutritious ingredient of wot and soups and sells for twice as much as common pea in local markets (Berhane Gebreslassie and Berhanu Abraha 2016).

Third place in area was chick pea, planted on $16.2 \%$ of the pulse area. Ethiopia is a secondary center of genetic diversity for chickpea and its wild relative Cicer cuneatum. As for other pulses it is an important fasting food. Mainly consumed by rural households in the past, an urban market has developed as people become more aware of the health benefits of a varied diet. A major advantage of chickpea is its drought resistance. It is almost always grown on residual soil moisture after other crops have been harvested (Yadeta Anbessa and Geletu Bejiga (2002). It is therefore "free" and does not occupy land on which less drought resistant crops must rely. Farmers widely exploit the characteristics of the hundreds of landraces of this crop. Local types are generally low yielding (although once again they are not in 
competition with other crops for land and other resources). Research interest concentrates on higher yields and better seed quality with a view to building an export market (which may possibly serve to supplement farmer income).

The grass pea was the fourth most important pulse in terms of area occupying $15.4 \%$ in 2019/2020. Northern Ethiopia is probably a primary center of origin for this species. It is resistant to drought, to salinity, and to waterlogging and is tolerant of low soil fertility. A major negative is its content of Oxalyldiaminopropionic acid (ODAP) which, when ingested, can cause neurolathyrism in humans, a motor neuron degenerative disease that results in lower-body paralysis (Dejene Girma and Lijalem Korbu 2012). As with other food crops there is considerable variation in the species related mainly to geography and altitude (Wuletaw Tadesse and Endashaw Bekele 2003). Research efforts to reduce the ODAP content have not been very successful this does not prevent its use as a food in a manner analogous to other pulses.

Lentils occupied $14.9 \%$ of the pulse area in $2019 / 2020$. Lentils are grown as a protein rich $(23-24 \%)$ nutritious food crop, as a marketable product locally which commands a high price and as an export crop. The seed, mostly split before further processing, is higher in protein, carbohydrate and calories than other legumes. It is used as main and side dishes, and in salads. Ground seeds are used in soups and wot and mixed with cereals in bread and cakes. Lentils are an excellent infant food (Matny 2015). Grown in rotation with cereals its nitrogen-fixing properties add to soil fertility and help to break cereal disease cycles (Edossa Fikiru et al. 2007).

Fenugreek is a very minor crop in Tigray, grown in very small plots on only 603 ha, almost all in the south of the State, in 2019/2020. In spite of this, several local cultivars are recognized by Tigrayan farmers. Its use as a food is similar to that of other pulses but the leaves are also used as a green vegetable. Fenugreek is moderately resistant to Cercospera leaf spot (Kassa Ashebre Melese 2020). Fenugreek seeds are a good source of essential metals, but also contain large amounts of toxic cadmium and lead (Mebrahtu Hagos and Chandravanshi 2016).

Haricot beans are not a traditional crop in Tigray. Many people will not eat them in the belief that they cause stomach upsets, and particularly flatulence. In spite if this there has been some uptake of haricot cultivation due to government pressure to increase exports of pulses (Tadesse Getachew 2019).

\subsection{Oil seeds}

In 2019/2020 oilseeds (Fig. 6) were sown in Tigray on 119570 ha, equivalent to 15.3\% of the cereal area, grown by 216195 families with an average oilseed area of 0.55 ha. The total output of 96121 tonnes resulted from an area yield of 0.80 tonne/ha.

Sesame, grown on 108291 ha in 2019/2020, was by far the major oilseed crop in Tigray but yielded only 0.75 tonnes/ha of seed (CSA 2021). This crop is largely confined to the lowland west and northwest of the State centered on the town of Humera close to the borders with Sudan and Eritrea, at an altitude of 600-900 meters. Sesame is produced by both smallholder farmers and small scale commercial farmers. 
Producers sell small quantities locally on the nearest market or through various kinds of associations. Some sesame is milled locally but most seed is exported - sesame is second only to coffee in Ethiopian export revenue. Ethiopian sesame is of renowned quality and commands a premium price in Israel and the United Arab Emirates where it is converted to tahini (Terefe Negasa Abebe 2016). Sales of sesame provide much needed cash for poor farmers with which they can buy food and other necessities, but it is certain that they do not receive the share of the final price to which they are entitled. More than 80 weed species have been identified as pests of sesame in western Tigray with Commelina foecunda being the most troublesome. Blight, powdery mildew, fusarium wilt, and leaf spot are major bacterial and fungal pests and may be transmitted by a leafhopper (Yirga Bilay Kinda et al 2018).

Niger seed, Guizotia abyssinica, more commonly referred to in Ethiopia by its demotic name of neug, is native to Ethiopia. The crop occupies about $40 \%$ of all oilseeds nationwide but is grown on less than $5 \%$ of the oil seed area in Tigray where its average yield in 2019/2021 was about 1.5 tonnes/ha (CSA 2021). The seed contains about $40 \%$ oil and $20 \%$ protein. Niger oil is highly prized on account of its light color and nutty taste. After pressing the residual cake, with up to 30 per cent protein, is a valuable livestock feed that is reserved mainly for work oxen. Yield losses due to various diseases and insect pests can be considerable. Leaf spots, stem and root rots, and mildews are the major pathogens. Insect pests include Lepidopteran larvae, stem borers and aphids, The niger capsule fly Dioxyna sororcula is an important pest of neug throughout its range (Schmutterer 1971).

At the national level, linseed is grown on about $10 \%$ of the total oil seed area but in Tigray it is less than $4 \%$ of that of oil seeds as a whole. Linseed crops yielded just about 1.0 tonne/ha in 2019/2020. Ethiopia is a secondary center of diversity for this crop where at least 203 landraces have been identified (Worku Negash Mhiret and Heslop-Harrison 2018). It is possible that Ethiopia's wide agroclimatic range has contributed to diversification in this oil crop (Birhanu Amare Gidey et al. 2020). In southern Tigray significant differences were observed among 12 genotypes in plant height, seed size, and days to maturity. The seed is used for oil whereas the stem converts to flax fiber. The oil content, which has drying properties, is in the range $35-44 \%$. Extracted oil is mostly for home use but some is marketed. The seed is roasted, ground and mixed with spices for eating with local bread, is used in soups, is an ingredient of wot and soft drinks, and is a constituent in porridges.

Castor, common mustard and safflower are very minor oilseed crops in Tigray. There is virtually no production of soybeans nor of peanuts. Oil extracted from minor crops is used locally for cooking.

\subsection{Spices}

Most of the world's known spices, many imported, are used in Ethiopian culinary practice. Those cultivated in the country are grown in small plots or intercropped with other food plants. In addition to cultivation some are collected in the wild (Jansen 1981). Use of these plants, many used in the traditional pharmacopeia (Meaza Gidey et al. 2015), and others that could produce essential oils, is not confined to Tigray but is similar throughout Ethiopia (Zuberi et al. 2014). The use and value of spices in Ethiopian 
cuisine cannot be overestimated as they are a part of most dishes and especially important in wot. Spices are also important items in local trade, providing diversified income, especially for women (Fig. 7).

The most widely grown and used spice in Ethiopia is the ubiquitous berbere, one or more species of Capsicum, usually known as chili in English, each of which may comprise several varieties. Mixed with other spices it is the basic hot ingredient of most wot dishes and can be found in every local market (Fig. 7). The crop is widely gown in small plots close to the house where it can be protected against theft and fertilized with the manure of the work oxen and other domestic stock It has been said of chili that "it requires such intensive care that it dominates the farmer's life, especially at the seedling production stage" (Tewolde Berhan Gebre Egziabher 1984). A very pungent variant is known as mitmita. Several concoctions are used to cure real or assumed illnesses. Various fungi can cause considerable reduction in yield, including leaf spots Cercospera spp., powdery mildew and root rot.

Small scale cultivation of coriander, Coriandrum sativum, provides a typical example of traditional production. Its planting is widespread and it is almost universal in local markets. Several varieties are distinguished based on life cycle (long or short growing season), disease resistance, yield, color and oil content. Leaves are used as an aromatic herb in bread, tea and wot, whereas the fruits have a wide range of uses including as an indispensable ingredient of berbere. As for coriander, cumin Cuminum cyminum and black cumin Nigella sativa are widely cultivated and are omnipresent in markets. Ethiopian mustard used for oil has high levels of undesirable glucosinolates and erucic acid (Getinet et al. 1997). The use and presence of other spices are listed in Table 1. Heavy losses of fruit for most spices can be caused by dipterous flies and most plants are susceptible to Fusarium wilts, mildews and root rots.

\subsection{Fruits and vegetables}

Official data for 2019/2020 indicate that just over 56000 households (4.5\% of all households) grew fruit crops on 937 ha ( $0.1 \%$ of all cultivated land) in Tigray. In the same year 327700 households (26\%), including those growing chili peppers, grew vegetables and root crops on 6060 ha $(0.64 \%$ of cultivated land) (CSA 2021). Fruits and vegetables are important sources of vitamins (especially Vitamin C), minerals and fiber and thus contribute health benefits. They also complement other food production in that fruits are perennial crops requiring little input and vegetables are short season crops that do not compete for labor and other inputs with the main cereal, pulse and oilseed crops. These products are grown for home consumption and for local sales. Women and children are the main beneficiaries of the output (physical and monetary) of these minor crops. Food value and income are both negatively affected by poor cultural practices and incorrect handling both in storage and in transport to markets (Hagos Abraha Rahiel 2018).

The fruits of prickly pear Opuntia ficus-indica, a species introduced to Eritrea by the Italian administration but now an invasive alien, are eaten by children at all times and generally by adults during famines. They are also a source of income and are sold in many Tigrayan markets. Among the cultivated fruits guava and lemons are most common both for home consumption and for sales. Other fruits (Table 1) are less commonly grown. 
Onions and garlic, universal basic ingredients in wot, are the most cultivated and most productive of all vegetables. Tomatoes - widely used in wot and other dishes - and Irish potatoes, spinach beet and cabbage are other main vegetables.

\subsection{Miscellaneous}

In addition to food crops Tigrayan farmers grow cotton and coffee as minor crops. Indigenous knowledge handed down generation after generation for hundreds of years is drawn on in times of need to use the non-cultivated natural resources of the region as famine food, as medicine and as a marketable product. Leaves, twigs, flowers, fruits and roots of many species are used in various ways for these purposes.

Cotton production is confined to the northwestern lowlands which are also the site of Sesame production. Yields are low due to poor agronomic practices and poor quality seed (Zenawi Gebregergis et al. 2020). Raw cotton is the basis of cottage weaving which adds a diversified source of income to poor households: modern commercial cotton weaving enterprises in Mekelle provide employment opportunities for urbanites. Coffee is another very minor crop, grown in the southern and eastern lowlands of the Region. A local landrace is the principal genetic resource. In spite of low yields and poor practice, such as mixing unripe and ripe berries for drying and improper storage "it is possible to produce high quality Tigray coffee for global market and enable the region to diversify foreign earnings largely to improve the livelihood of rural people in the region" (Abrar Sualeh and Negussie Mekonnen 2013).

Buckthorn, Rhamnus prinoides, is predominately a wild shrub that grows at altitudes of $1500-2500$ meters, but because of its many qualities and uses trees may be planted close to the homestead. It flowers and fruits all year round. The leaves and woody parts are used in brewing of tella and tej, and in the distillation of araki from either of these. Buckthorn, like hops in western brewing, imparts a slightly bitter flavor to the drink (Nigussie et al. 2020).

Impatiens tinctoria is commonly harvested from the wild although it is also grown as a cash crop in parts of Tigray (Cronin et al. 2013). It is a popular dye plant that is also used medicinally. Women mash the tuberous roots (Fig. 7) into a paste that is left to steep for 12 hours. The mash is then heated and the paste applied to the palms and nails of the hands (for young girls) or to the hands and feet (adult women) to dye them in intricate patterns in a dark reddish color. This beauty treatment also helps to control fungal infections and toughen the skin. The product is used to dye cloth and is an ingredient of a red ink (Sileshi Degu et al. 2020).

Christ thorn (or Christ thorn jujube) Ziziphus spina-christi is a widespread species across northen Africa. It is truly a multipurpose wild tree and is sometimes considered an invasive alien. Best known for its edible fruits, which are high in Vitamin $C$ and are eaten raw, it is also a useful firewood tree, makes excellent charcoal and has medicinal uses mainly as a cure for dandruff (Fitsumbirhan Tewelde 2018).

Sometimes known as the soapberry, the most common use of Phytolacca dodecandra is as a soap and a shampoo. The dried and powdered berries are also used to stun fish, to kill snails, and are possibly effective in controlling schistosomiasis (Kebede Taye Desta and Abd El-Aty 2021). An extract is also 
effective in controlling chocolate spot on pulses (Addisu Tegegn et al. 2019). It is widespread in the wild and is preserved in churchyards (Wilson 1977).

Tapeworm infestation in humans was very common in the past and persists to some extent to the present and results from eating raw beef. Many plants are believed to be curative for this problem. The dried flowers of Hagenia abyssinica are, however, the most widely used of all tapeworm expellents (Edilu Jorga et al. 2020). The monthly cure is a strong purgative and often cause a strong debilitating reaction. The second most common wild plant treatment for tapeworms is Embelia schimperi, whose dried fruits are the main active ingredient (Yared Debebe et al. 2015). The use of Embelia as a tapeworm cure is not confined to Ethiopia as it is also found in Tanzania and Kenya (Bøgh et al. 1996).

Various parts of Rumex abyssinicus are used for a variety of reasons. As for the two previous plants it is considered to be a vermicide and is also a cure for headaches (Fitsumbirhan Tewelde 2018). It has been recorded as reducing hypertension (Gidey Yirga 2010), a dried preparation of the root has antibacterial properties (Zelalem Gudeta Abdi and Dula Daksa Ejeta 2019), and preparations of the root are used in a drink and to prepare a cosmetic dye as for Impatiens tinctoria

\section{Discussion}

Tigray is home to more than 5.7 million people, about $75 \%$ of whom are rural small scale farmers. Much of the area has low and erratic rainfall and soil nutrients have been depleted over many hundreds of years of agricultural exploitation. The varied agroclimatic conditions nonetheless support a rich diversity of wild and cultivated plants (Harlan 1969). Biodiversity contributes to food, medicine, textile, fiber, fuelwood, and other resources essential to human survival.

Ethiopia (including especially Tigray) is an important center of origin of biodiversity. Farmers are well aware of and make use of these resources by selecting and using the several species and possibly hundreds of landraces in what is, essentially, their struggle for survival. Diversity allows farmers to garner over an extended period within the year a range of varied and valuable food and non-food products. Loss of diversity reduces food choices and affects food and nutrition security in addition to resilience to change. Biodiversity has, however, been declining in recent years. This decline is attributed to both natural and anthropogenic pressures. These pressures can be categorized as: i) environmental (climate change, land use and cover changes, invasive and alien species; ii) social (demographic change, urbanization, rural development; iii) economic ( replacement of traditional crops and varieties with higher yielding ones, commercialization, global markets, consumer food preferences, government policy, labor shortages); iv) cultural (modernization, taboos, loss of traditional knowledge, customary practices; and, v) governance and institutions (poverty, civil strife, military operations).

Tigrayan farmers have proved to be very adaptable and resilient to continually changing contexts. The mining of the limited areas of land suitable for agriculture coupled to a population constantly on the increase do, however, make it more and more difficult to provide enough food for their families and produce a surplus for sale. Urbanization will exacerbate food insecurity and increase poverty as fewer 
farmers produce less food. Urban immigrants rarely find remunerative employment and "idle hands are the devil's workshop", contributing to civil unrest and antagonism between town and country.

Modern research tends to diminish biodiversity as it often ignores indigenous knowledge and strives for higher yields, which may mean more expensive inputs, in a few selected crops. More effort is needed in the areas of research, development, and policy. Political commitment, policy development and enforcement, and a participatory approach are critical for long-term production increases whilst ensuring that the region's unique natural resources are not diminished. Tigray's farmers are making the best use they can of these resources but would be helped to improve their welfare and livelihoods

Varietal diversity in crops increases crop production and food security. Government policy and the extension services should encourage diversity in addition to promoting increased production. Constraints to higher output include irrelevant research, limited availability of improved varieties, lack of a formal seed delivery system, and reluctance of farmers to adopt improved genetics and new technology. Tigray's farmers struggle to survive but in feeding themselves and contributing to the national food bank they deserve more support than they are given.

\section{Declarations}

Acknowledgments The genesis of this paper (1974-1975) was the Tigre Rural Development Study financed by the UK Government on which the Author was a Livestock and Range Management Specialist. Intermediate opportunistic visits to Tigray were at the expense of the Food and Agriculture Organization, the World Bank and the Dutch Government. Partial financing of the Author's cost of the later phase (2018), which was part of an attempt to assess the outcome of the initial stage, was provided by Neil Munro. Most thanks are due, however, to the countless Tigrayan men, women and children on farms and at markets who willingly imparted their knowledge and shared their experiences with the Author.

Funding No external funding was used in preparation of this paper.

\section{Compliance with ethical standards}

Conflict of interest The author declares no conflict of interest.

Ethics approval Not required.

Consent for participation Not required.

Consent for publication Not required.

Consent statement All the people who took part in discussion regarding this paper were aware of the reason for the discussions and gave their consent to the information they supplied being included in a published paper 


\section{References}

Abebaw Dessie. (2018). Cereal crops research achievements and challenges in Ethiopia. International Journal of Research Studies in Agricultural Sciences, 4(6), 23-29. http://dx.doi.org/10.20431/24546224.0406003.

Abrar Sualeh, \& Negussie Mekonnen. (2013). Evaluation of coffee quality of Tigray Regional State, Ethiopia (Case Study Raya Azebo District). Prudence Journal of Agricultural Research, I, 3-6.

Addisu Tegegn, Meseret C. Egigu, \& Bekele Hundie. (2019). Evaluation of endod (Phytolacca dodecandra L.) extracts against Botrytis fabae, a causative agent of Chocolate Spot Disease of Vicia faba. Cogent Food \& Agriculture, 5, 1, 1686948. https://doi.org/10.1080/23311932.2019.1686948.

Afework Bekele, \& Leirs, H. (1997). Population ecology of rodents of maize fields and grassland in central Ethiopia. Belgian Journal of Zoology 127(Supplement), 39-48.

Amare Sisay Tefera, Ayoade, J. O., \& Bello, N. J. (2019). Drought occurrence pattern in Tigray Region, northern Ethiopia. Journal of Applied Sciences and Environmental Management, 23, 1341-1348. https://dx.doi.org/10.4314/jasem.v23i7.23.

Awegechew Teshome, Baum, B. R., Fahrig, L., Torrance, J. K., Arnason, J. T. \& Lambert, J. D. H. (1997). Sorghum [Sorghum bicolor (L.) Moench] landrace variation and classification in North Shewa and South Welo, Ethiopia. Euphytica, 97, 255-263. https://doi.org/10.1023/A:1003074008785.

Awegechew Teshome, Torrance, J. K., Baum, B., Fahrig, L., Lambert, J. D. H. \& Arnason, J. T.. (1999). Traditional farmers' knowledge of sorghum (Sorghum bicolor [Poaceae]) landrace storability in Ethiopia. Economic Botany, 53, 69-78. https://doi.org/10.1007/BF02860794.

Berhane Gebreslassie and Berhanu Abraha. (2016). Review: distribution and productivity of dekoko (Pisum sativum var. abyssinicum A. Braun) in Ethiopia. Global Journal of Science Frontier Research: C Biological Science 16, 44-57.

Bethlehem Melese, Neela Satheesh, \& Solomon Workneh Fanta. (2019). Emmer wheat - an Ethiopian prospective: a short review. Annals. Food Science and Technology, 20, 89-96.

Bijlmakers, H. (1989). Insect pests of cereals in Ethiopia: identification and control methods. FAO/UNDP Project ETH/86/029. Addis Ababa: Food and Agriculture Organization.

Birhanu Amare, \& Tsehaye Birhane. (2020). On farm demonstration of faba bean (Vicia faba I.) varieties in orobanche infested areas of Ofla District, South Tigray, Ethiopia. International Journal of Agricultural Science and Food Technology, 6, 171-175. https://dx.doi.org/10.17352/2455-815X.000069.

Birhanu Amare Gidey, Kiflom Kahsay, \& Netsanet Kidane. (2020). Yield evaluation and character association of linseed (Linum usitatissimum L.) genotypes in moisture stress areas of South Tigray, 
Ethiopia. Journal of Cereals and Oilseeds, 11, 16-20. https://doi.org/10.5897/JC02020.0208.

Bøgh, H. O., Andreassen, J., \& Lemmich, J. (1996). Anthelmintic usage of extracts of Embelia schimperi from Tanzania. Journal of Ethnopharmacology, 50, 35-42. https://doi.org/10.1016/03788741(95)01322-9.

Bruce, J. (1790). Travels to Discover the Source of the Nile in the Years 1768, 1769, 1770, 1771, 1772, and 1773. In Five Volumes by James Bruce of Kinnaird, Esq. F.R.S. London: G.G.J. and J. Robinson. [Information from Author's personal First Edition copy].

Cronin, M., Lamond, G., Pagella, T., Sinclair, F., Aster Gebrekirstos, \& Kiros Hadgu. (2013). Local agroecological knowledge of sustainable intensification of the tree-crop-livestock system in the Ethiopian Highlands, Endamahoni Woreda, Tigray Region. Nairobi: International Livestock Research Institute.

CSA. (2018). The 2015/16 Ethiopian Household Consumption-Expenditure (HCE) Survey: Results for Tigray Region (Statistical Bulletin 585-1). Addis Ababa: Central Statistical Agency.

CSA. (2021). Agricultural Sample Survey (2020/21 (2013 E.C.): Volume I, Report on Area and Production of Major Crops (Private Peasant Holdings, Meher Season) (Statistical Bulletin 590). Addis Ababa: Central Statistical Agency

D'Andrea, A. C., \& Mitiku Haile. (2002). Traditional emmer processing in Highland Ethiopia. Journal of Ethnobiology, 22, 179-217.

Dawit Abate. (2017). Ergotism and the ergot fungus in Ethiopia. Annual Congress on Mycology and Fungal Infections; November 16-17, 2017 Atlanta, Georgia, USA. Journal of Experimental and Clinical Microbiology Special Issue: Microbiology and Biotechnology Reports. Available at:

https://www.pulsus.com/proceedings/ergotism-and-the-ergot-fungus-in-ethiopia-298.html. Accessed 10 August 2021.

Dejene Girma, \& Lijalem Korbu. (2012). Genetic improvement of grass pea (Lathyrus sativus) in Ethiopia: an unfulfilled promise. Plant Breeding, 131, 231-236. https://doi.org/10.1111/j.1439-0523.2011.01935.x.

Dove, K. (1890). Kulturzonen von Nord-Abessinien (in German) [Cultural zones of northern Abyssinia]. Petermann's Geographische Mitteilungen, Ergaenzungsheft 97. Gotha, Germany: Justus Perthes.

Edilu Jorga, Van Damme, I., Bizunesh Mideksa, \& Gabriël, I. (2020). Identification of risk areas and practices for Taenia saginata taeniosis/cysticercosis in Ethiopia: a systematic review and meta-analysis. Parasites and Vectors, 13, 375. https://doi.org/10.1186/s13071-020-04222-y.

Edossa Fikiru, Kassahun Tesfaye, \& Endashaw Bekele. (2007). genetic diversity and population structure of Ethiopian lentil (Lens culinaris Medikus) landraces as revealed by ISSR marker. African Journal of Biotechnology, 6, 1460-1468. 
Elisabetta Gotor, Muhammed Abdella Usman, Martina Occelli, Basazen Fantahun, Carlo Fadda, Yosef Gebrehawaryat Kidane, Dejene Mengistu, Afewerki Yohanne Kiros, Jemal Nurhisen Mohammed, Mekonen Assefa, Tesfaye Woldesemayate, \& Caracciolo, F. (2021). Wheat varietal diversification increases Ethiopian smallholders' food security: evidence from a participatory development initiative. Sustainability, 13, 1029. https://doi.org/10.3390/su13031029.

FAO. (2016). Ethiopia Situation Report. Addis Ababa: Food and Agriculture Organization. http://www.fao.org/fileadmin/user_upload/emergencies/docs/FAO\%20Ethiopia _El\%20Nino\%20Situation\%20Report_February\%202016.pdf. Accessed 31 August 2021.

Firew Mekbib. (2008). Farmers' breeding of sorghum in the centre of diversity, Ethiopia: I. socio-ecotype differentiation, varietal mixture and selection efficiency. Journal of New Seeds, 9, 43-67. https://doi.org/10.1080/15228860701879299.

Fitsumbirhan Tewelde. (2018). Marketable medicinal, edible and spice plants in Endasilase-Shire District Tigray Regional State, Ethiopia. Research Journal of Medicine and Medical Sciences, 13, 1-6.

Gebrehiwot Weldegebrial Gebru, \& Fekadu Beyene. (2012). Rural household livelihood strategies in drought-prone areas: a case of Gulomekeda District, Eastern Zone of Tigray National Regional State, Ethiopia. Journal of Development and Agricultural Economics, 4, 158-168. https://doi.org/ 10.5897/jsppr11.073.

Gemechu Keneni, Mussa Jarso, Tezera Wolabu, \& Getnet Dino. (2005). Extent and pattern of genetic diversity for morpho-agronomic traits in Ethiopian highland pulse landraces: I. Field pea (Pisum sativum L.). Genetic Resources and Crop Evolution, 52, 539-549.

Getinet, A., Rakow, G., Raney, J. P., \& Downey, R. K. (1997). Glucosinolate content in interspecific crosses of Brassica carinata with B. juncea and B. napus. Plant Breeding, 116, 39-46. https://doi.org/10.1111/j.1439-0523.1997.tb00972.x.

Haddis Yirga, \& Dargie Tsegai. (2013). Characterization of dekoko (Pisum sativum var. abyssinicum) accessions by qualitative traits in the highlands of Southern Tigray, Ethiopia. African Journal of Plant Science, 7, 482-487. https://doi.org/10.5897/AJPS2013.1092.

Hagos Abraha Rahiel, Abraha Kahsay Zenebe, Gebreslassie Woldegiorgis Leake, \& Beyene Weldegerima Gebremedhin. (2018). Assessment of production potential and post-harvest losses of fruits and vegetables in Northern Region of Ethiopia. Agriculture \& Food Security, 7, 29. https://doi.org/10.1186/s40066-018-0181-5.

Hailemichael Shewayrga, \& Sopade, P. A. (2011). Ethnobotany, diverse food uses, claimed health benefits and implications on conservation of barley landraces in North Eastern Ethiopia highlands. Journal of Ethnobiology and Ethnomedicine, 7, 19. http://www.ethnobiomed.com/content/7/1/19. 
Hailu Feyis Tasisa, Chemada Brihanu Chela1, Dagnachew Lule, \& Kebede Dessalegn Lemu. (2021). Onfarm evaluation and pre-scaling up of improved finger millet technologies under rainfed condition in Western Oromia, Ethiopia: a case of East Wollega Zone, Ethiopia. Journal of Agricultural Extension and Rural Development, 13, 165-172. https://doi.org/10.5897/JAERD2021.1241.

Harlan, J. R. (1969). Ethiopia: a center of diversity. Economic Botany, 23, 309-314. https, //doi.org/10.1007/BF02860676.

Hintsa Gebru, Abraha Hailemariam, \& Tesfay Belay. (2011). Genotype by environment interaction and grain yield stability of early maturing bread wheat (Triticum aestivum L.) genotypes in the drought prone areas of Tigray Region, Northern Ethiopia. Ethiopian Journal of Applied Science and Technology, 2: 5157.

Huffnagel, H. P. (1961). Agriculture in Ethiopia. Rome: Food and Agriculture Organization.

Jansen, P. C. M. (1981). Spices, condiments and medicinal plants in Ethiopia, their taxonomy and agricultural significance. Wageningen, The Netherlands: PUDOC.

Jemal Mohammed, Semeneh Seleshi, Fetene Nega, \& Moohal Lee. (2016). Revisit to Ethiopian traditional barley-based food. Journal of Ethnic Foods, 3, 135-141. https://doi.org/10.1016/j.jef.2016.06.001.

Kassa Ashebre Melese, Teklhaimanot Gebremichael, Abrhaley Shelema, \& Birtukan Gebrekiros. (2020). Field performance evaluation of different fenugreek (Trigonella foenum-graecum L.) genotypes in Northern Ethiopia of Southern Tigray. Egyptian Academic Journal of Biological Sciences H. Botany, 11, 35-39. https://doi.org/10.21608/eajbsh.2020.128002.

Kebede Taye Desta, \& Abd El-Aty, A. M. (2021). Triterpenoid and saponin rich Phytolacca dodecandra I'herit (endod): a review on its phytochemistry and pharmacological properties. Mini Reviews in Medical Chemistry, 21, 23-34. https://doi.org/10.2174/1389557520666200617110241.

Ladizinsky, G. (1975). Oats in Ethiopia. Economic Botany, 29, 238-241. https://doi.org/10.1007/BF02873171.

Lijalem Gebrewahid, Dejene K. Mengistu, Yemane Tsehaye, Addis Aberha, \& Dereje A. Aberra. (2021). Variability among Ethiopian durum wheat genotypes grown under different climatic conditions of Tigray for some agronomic and grain-quality traits. Journal of Crop Improvement, 35, 184-203. https://doi.org/10.1080/15427528.2020.1806979.

Matny, O. N. (2015). Lentil (Lens Culinaris Medikus) Current status and future prospect of production in Ethiopia. Advances in Plants \& Agriculture Research, 2, 45-53.

Meaza Gidey, Tadesse Beyene, Signorini, M. A., Bruschi, P., \& Gidey Yirga. (2015). Traditional medicinal plants used by Kunama Ethnic Group in Northern Ethiopia. Journal of Medicinal Plants Research, 9, 494509. https://doi.org/10.5897/JMPR2014.5681. 
Mebrahtu Hagos, \& Chandravanshi, B. S. (2016). Levels of essential and toxic metals in fenugreek seeds (Trigonella foenum-graecum l.) cultivated in different parts of Ethiopia. Brazilian Journal of Food Technology, 19, e2015059. http://dx.doi.org/10.1590/1981-6723.5915.

Mooha Lee, Meron Regu, \& Semeneh Seleshe. (2015). Uniqueness of Ethiopian traditional alcoholic beverage of plant origin, tella, Journal of Ethnic Foods, 2, 110-114. https://doi.org/10.1016/j.jef.2015.08.002.

Munro, R. N., Teweldeberhan Woldegerima, Berhane Hailu, Amanuel Zenebe, Zemichael Gebremedhin, Abrha Hailemichael, \& Nyssen, J. (2019). A history of soil and water conservation in Tigray. In J Nyssen et al. (Eds.) Geo-trekking in Ethiopia's Tropical Mountains, GeoGuide (pp. 477-493). Basel: Springer Nature. https://doi.org/10.1007/978-3-030-04955-3_32.

Nega Gebreselassie Wubeneh, \& Sanders, J. H. (2006). Farm-level adoption of sorghum technologies in Tigray, Ethiopia. Agricultural Systems, 91, 122-134. https://doi.org/10.1016/j.agsy.2006.02.002.

Nigussie Seboka Tadesse, Girum Faris Beyene, Tesfaye Bekele Hordofa, \& Ashenafi Ayenew Hailu. (2020). Traditional foods and beverages in Eastern Tigray of Ethiopia. Journal of Ethnic Foods, 7, 16. https://doi.org/10.1186/s42779-020-00050-8.

Schmutterer, H. (1971). Contribution to the knowledge of the crop pest fauna in Ethiopia. Journal of Applied Entomology, 67, 371-389. https://doi.org/10.1111/j.1439-0418.1971.tb02136.x.

Sileshi Degu, Negero Gemeda, Abiy Abebe, Asfaw Berihun, Eyob Debebe, Bihonegni Sisay, et al. (2020). In vitro antifungal activity, phytochemical screening and thin layer chromatography profiling of Impatiens tinctoria A. Rich root extracts. Journal of Medicinal Plants Studies, 8, 189-196.

Tadesse Getachew. (2019). Pulse crops production opportunities, challenges and its value chain in Ethiopia: a review article. Journal of Environment and Earth Science, 9, 20-29. https://doi.org/10.7176/JEES/9-1-03.

Terefe Negasa Abebe. (2016). Review of sesame value chain in Ethiopia. International Journal of African and Asian Studies, 19, 36-47.

Tesfay Gebrekirstos, Gebremariam, Getaneh Woldeab, \& Thangavel Selvaraj. (2016). Distribution, physiologic races and reaction of wheat cultivars to virulent races of leaf rust (Puccinia Triticina Eriks and Henn.) in South Eastern Zone of Tigray, Ethiopia. International Journal of Life Sciences, 4, 1-21.

Tewolde Berhan Gebre Egziabher. (1984). Some important New World plants in Ethiopia. In S. Rubensten (Ed.), Proceedings of the Seventh International Conference of Ethiopian Studies, Lund, 26-29 April 1982 (pp. 187-194). Addis Ababa: Institute of Ethiopian Studies/Uppsala: Scandinavian Institute of African Studies. 
UN. (2018). World Urbanization Prospects 2018 Revision. New York NY: Department of Economic and Social Affairs, Population Division, United Nations.

Vavilov, N. I. (1935). Origin and geography of cultivated plants. In D. Love (Trans.), The phytogeographical basis for plant breeding (pp. 316-366). Cambridge, UK: Cambridge University Press

Vavilov, N. I. (1951). K. S. Cheter (Trans.), The origin, variation, immunity and breeding of cultivated plants. Waltham, MA: The Chronica Botánica Co.

Vogt, Y. (1975). Rural Development Study, Central Tigre, Ethiopia, Annex 4 Agriculture, Appendix A. Boreham Wood, UK: Hunting Technical Services Ltd.

WFP. (2009). Food security and vulnerability in selected towns of Tigray Region, Ethiopia. Addis Ababa: World Food Programme-Ethiopia.

Wilson, R. T. (1977). The vegetation of Central Tigre, Ethiopia, in relation to its land use. Webbia, 32, 235270. https://doi.org/10.1080/00837792.1977.10670095.

Wilson, R. T. (2003). The environmental ecology of oxen used for draught power. Agriculture, Ecosystems and Environment, 97, 21-37. https://doi.org/10.1016/S0167-8809(03)00118-X.

Worku Negash Mhiret, \& Heslop-Harrison, J. S. (2018). Biodiversity in Ethiopian linseed (Linum usitatissimum L.): molecular characterization of landraces and some wild species. Genetic Resources and Crop Evolution, 65, 1603-1614. https://doi.org/10.1007/s10722-018-0636-3.

Wuletaw Tadesse, \& Endashaw Bekele. (2003). Phenotypic diversity of Ethiopian grass pea (Lathyrus sativus L.) in relation to geographical regions and altitudinal range. Genetic Resources and Crop Evolution, 50, 497-505. https://doi.org/10.1023/A:1023923813312.

Yadeta Anbessa and Geletu Bejiga. (2002). Evaluation of Ethiopian chickpea landraces for tolerance to drought. Genetic Resources and Crop Evolution, 49, 557-564. https://doi.org/10.1023/A:1021210601480.

Yared Debebe, Mesfin Tefera, Walelign Mekonnen, Dawit Abebe, Samuel Woldekidan, Abiy Abebe1, et al. (2015). Evaluation of anthelmintic potential of the Ethiopian medicinal plant Embelia schimperi in vivo and in vitro against some intestinal parasites. BMC Complementary and Alternative Medicine, 15, 187. https://doi.org/10.1186/s12906-015-0711-7.

Yemane Tsehaye, T. Berg, Bayush Tsegaye, \& Tesema Tanto. (2006). Farmers' management of finger millet (Eleusine coracana I.) diversity in Tigray, Ethiopia and implications for on-farm conservation. Biodiversity and Conservation, 15, 4289-4308. https://doi.org/10.1007/s10531-005-3581-3.

Yirga Belay Kindeya, Weres Negash Golla, Asefa Abadi Kebede, and Fiseha Baraki Sibhatu. (2018). Survey and identification of major sesame diseases in low land areas of Western Zone of Tigray, 
Ethiopia. Journal of Biomaterials, 2, 58-64. https://doi.org/10.11648/j.jb.20180202.16.

Zelalem Gudeta Abdi, \& Dula Daksa Ejeta. (2019). Isolation, characterization and antibacterial activities evaluation of Rumex abyssinicus rootbark extracts. International Journal of Scientific \& Engineering Research, 10, 1912-1927.

Zenawi Gebregergis, Fiseha Baraki, \& Goitom Teame. (2020). Planting geometry of cotton under rain fed condition in the dry land areas of Western Tigray. Cogent Food \& Agriculture, 6, 1, 1771113. https://doi.org/10.1080/23311932.2020.1771113.

Zeven, A. C. (1991). Wheats with purple and blue grains: a review. Euphytica, 56, 243-258. https://doi.org/ 10.1007/BF00042371Corp.

Zuberi, M. I., Birhanu Kebede, Teklu Gosaye, \& Belachew Oloika. (2014). Species of herbal spices grown in the poor farmers' home gardens of West Shoa, Highlands of Ethiopia: an ethnobotanical account. Journal of Biodiversity and Environmental Sciences, 4, 164-185.

\section{Tables}

Table 1. Partial catalogue of food groups and foods within groups made use of in Tigrayan agriculture 


\begin{tabular}{|c|c|c|c|c|}
\hline English name & Latin binomial & $\begin{array}{l}\text { Tigrinya } \\
\text { name }\end{array}$ & $\begin{array}{l}\text { Amharic } \\
\text { name }\end{array}$ & Crop use and notes \\
\hline \multicolumn{5}{|l|}{ Cereals } \\
\hline Tef (white) & Eragrostis tef & tenda teff & ketch teff & Preferred cereal for 'njera' \\
\hline Tef (red) & Eragrostis tef & kayih teff & kay teff & Preferred cereal for 'njera' \\
\hline Wheat (hard) & Triticum durum & sengye & sindie & Flour for 'ambasha' and pasta \\
\hline Wheat (soft) & $\begin{array}{l}\text { T. aestivum }(\mathrm{T} . \\
\text { vulgare })\end{array}$ & & kollo & $\begin{array}{l}\text { Flour for bread; roast grain ('kollo') } \\
\text { as snack }\end{array}$ \\
\hline $\begin{array}{l}\text { Wheat } \\
\text { (emmer) }\end{array}$ & $\begin{array}{l}\text { T. dicoccum } \\
\text { abyssinicum }\end{array}$ & ares & aja & $\begin{array}{l}\text { Local porridge 'g'at'; traditional } \\
\text { bread 'kita'; 'kollo'; food for lactating } \\
\text { mothers and babies }\end{array}$ \\
\hline Barley & $\begin{array}{l}\text { Hordeum } \\
\text { sativum }\end{array}$ & segem & gebs & Malted for local beer 'tella'; 'g'at' \\
\hline Finger millet & $\begin{array}{l}\text { Eleusine } \\
\text { coracana }\end{array}$ & dagusha & dagusa & $\begin{array}{l}\text { 'tella'; flour mixed with wheat flour } \\
\text { for 'ambasha' }\end{array}$ \\
\hline $\begin{array}{l}\text { Sorghum } \\
\text { (white) }\end{array}$ & $\begin{array}{l}\text { Sorghum } \\
\text { bicolor }\end{array}$ & mashilla & mashilla & 'tella'; mixed with tef for 'njera' \\
\hline Sorghum (red) & & lequa & zengada & 'tella'; mixed with tef for 'njera' \\
\hline $\begin{array}{l}\text { Maize } \\
\text { (yellow) }\end{array}$ & Zea mays & $\begin{array}{l}\text { mashilla } \\
\text { bahri }\end{array}$ & bokollo & $\begin{array}{l}\text { flour mixed with wheat flour for } \\
\text { baking 'hanza'; cobs and seeds } \\
\text { roasted and boiled }\end{array}$ \\
\hline \multicolumn{5}{|l|}{ Pulses } \\
\hline $\begin{array}{l}\text { Bean (field, } \\
\text { horse) }\end{array}$ & $\begin{array}{l}\text { Vicia faba var. } \\
\text { abyssinica }\end{array}$ & $\begin{array}{l}\text { alkuay; } \\
\text { atabahri }\end{array}$ & bakella & $\begin{array}{l}\text { Split beans in 'kiki wot'; paste for } \\
\text { 'shira (= fasting) wot'; roasted }\end{array}$ \\
\hline Field pea & Pisum sativum & ini ater & ater & Flour in 'shira wot' \\
\hline Chickpea & Cicer arietinum & ater & chimbra & $\begin{array}{l}\text { Pounded to flour; whole grain in } \\
\text { 'wot'; roasted }\end{array}$ \\
\hline Grass pea & $\begin{array}{l}\text { Lathyrus } \\
\text { sativus }\end{array}$ & $\begin{array}{l}\text { asebere; } \\
\text { sebere }\end{array}$ & enguaya & Ground with pepper for 'shira wot' \\
\hline Lentil & Lens esculenta & burshin & mesir & Split grain in 'wot' \\
\hline Fenugreek & $\begin{array}{l}\text { Trigonella } \\
\text { foenum- } \\
\text { graecum }\end{array}$ & abaeke & abish & $\begin{array}{l}\text { Medicine, soft drink, 'wot'; also used } \\
\text { as a spice }\end{array}$ \\
\hline Bean (haricot) & $\begin{array}{l}\text { Phaseolus } \\
\text { vulgaris }\end{array}$ & adengura & adenguare & Little local use; export market \\
\hline
\end{tabular}


Oilseeds

\begin{tabular}{|c|c|c|c|c|}
\hline Sesame & $\begin{array}{l}\text { Sesamum } \\
\text { indicum }\end{array}$ & selit & selete & $\begin{array}{l}\text { Oil for cooking; soft drink; } \\
\text { flavouring 'wot'; mainly marketed } \\
\text { for export }\end{array}$ \\
\hline $\begin{array}{l}\text { Neug; niger } \\
\text { seed }\end{array}$ & $\begin{array}{l}\text { Guizotia } \\
\text { abyssinica }\end{array}$ & neug & neug & $\begin{array}{l}\text { Oil extraction; cake as livestock } \\
\text { feed }\end{array}$ \\
\hline Linseed & $\begin{array}{l}\text { Linum } \\
\text { usitatissimum }\end{array}$ & ent'ate & telba & $\begin{array}{l}\text { Oil; pounded and mixed with water } \\
\text { as drink; pounded and mixed in } \\
\text { 'wot'; flax }\end{array}$ \\
\hline Castor & $\begin{array}{l}\text { Ricinus } \\
\text { communis }\end{array}$ & guli & gulo & $\begin{array}{l}\text { Oil used to lubricate cooking plate } \\
\text { for 'njera' }\end{array}$ \\
\hline Mustard & $\begin{array}{l}\text { Brassica } \\
\text { carinata }\end{array}$ & $\begin{array}{l}\text { hamli } \\
\text { (leaf); } \\
\text { hadri } \\
\text { (grain) }\end{array}$ & gomen-zur & $\begin{array}{l}\text { Leaf vegetable; oil for cooking; } \\
\text { preparation of 'njera' }\end{array}$ \\
\hline Safflower & $\begin{array}{l}\text { Carthamus } \\
\text { tinctorius }\end{array}$ & shuf & suf & Oil for cooking; whole grain roastec \\
\hline
\end{tabular}

\section{Spices}

$\begin{array}{llll}\text { Pepper (red) Capsicum sp. berbere berbere } & \begin{array}{l}\text { Whole dark red/black pod ground to } \\ \text { powder with other spices; flavouring } \\ \text { for 'wot' }\end{array}\end{array}$

\begin{tabular}{lllll} 
Pepper (black) & Piper nigrum & $\begin{array}{l}\text { selim } \\
\text { berbere }\end{array}$ & $\begin{array}{l}\text { tikur } \\
\text { berbere }\end{array}$ & $\begin{array}{l}\text { Whole pod ground to powder; } \\
\text { flavouring for 'wot'; spice in tea }\end{array}$ \\
\hline Clove & $\begin{array}{l}\text { Syzygium } \\
\text { aromaticum }\end{array}$ & kinfer & kinfer & Ground flower buds added to tea \\
\hline
\end{tabular}

Ginger $\begin{aligned} & \text { Zingiber } \\ & \text { officinale }\end{aligned} \quad$ dendabile zingible $\quad \begin{aligned} & \text { Pounded dried rhizomes for } \\ & \text { flavouring 'wot' }\end{aligned}$

$\begin{array}{llll}\text { Coriander } & \begin{array}{l}\text { Coriandrum tsagha dembilal } \\ \text { sativum }\end{array} & \begin{array}{l}\text { Seed pounded and mixed with } \\ \text { peppers for 'dura wot' }\end{array}\end{array}$

Cumin commun $\begin{aligned} & \text { camon; } \\ & \text { cyminum } \\ & \text { azimudi }\end{aligned} \quad$ Pounded seed for flavouring 'wot'

$\begin{array}{llll}\text { Black cumin Nigella sativa azmud } & \begin{array}{l}\text { tikur } \\ \text { azmud }\end{array} & \begin{array}{l}\text { Ground seed mixed with other } \\ \text { peppers and added to 'wot' }\end{array}\end{array}$

\begin{tabular}{|lllll}
$\begin{array}{l}\text { Ethiopian } \\
\text { caraway }\end{array}$ & $\begin{array}{l}\text { Trachyspermum } \\
\text { ammi }\end{array}$ & azmud & $\begin{array}{l}\text { netch } \\
\text { azmud }\end{array}$ & $\begin{array}{l}\text { Ground seed mixed with other } \\
\text { peppers and added to 'wot' }\end{array}$ \\
\hline Turmeric & Curcuma longa & irdi & ird & $\begin{array}{l}\text { Powdered root added to 'wot' for } \\
\text { yellow colouring }\end{array}$
\end{tabular}

$\begin{array}{lll}\text { Ruta } & \text { chena tena adam } & \begin{array}{l}\text { Pounded capsule mixed with vetch } \\ \text { and added to 'wot'; also medicinal } \\ \text { plant for stomach ache }\end{array}\end{array}$




\begin{tabular}{|c|c|c|c|c|}
\hline Neug & $\begin{array}{l}\text { Guizotia } \\
\text { abyssinica }\end{array}$ & awesda & $\begin{array}{l}\text { tikur } \\
\text { azmud }\end{array}$ & $\begin{array}{l}\text { Ground seed mixed with peppers } \\
\text { and added to 'wot; }\end{array}$ \\
\hline $\begin{array}{l}\text { Ethiopian } \\
\text { mustard }\end{array}$ & $\begin{array}{l}\text { Brassica } \\
\text { carinata }\end{array}$ & senafetch & senafetch & $\begin{array}{l}\text { Ground seed with peppers and used } \\
\text { as sauce for 'njera' }\end{array}$ \\
\hline Long pepper & Piper longum & tinzez & timiz & $\begin{array}{l}\text { Ground fruit mixed with peppers } \\
\text { and added to 'wot' }\end{array}$ \\
\hline $\begin{array}{l}\text { African } \\
\text { cardamom }\end{array}$ & $\begin{array}{l}\text { Aframomum } \\
\text { corrorima }\end{array}$ & korerima & korerima & $\begin{array}{l}\text { Ground nut mixed with peppers and } \\
\text { added to 'wot'; flavouring for coffee; } \\
\text { Ethiopian endemic }\end{array}$ \\
\hline Basil & $\begin{array}{l}\text { Ocimum? } \\
\text { gratissimum }\end{array}$ & seseg & basobila & $\begin{array}{l}\text { Fruit husks ground with vetch and } \\
\text { added to 'shura wot' }\end{array}$ \\
\hline \multicolumn{5}{|c|}{ Fruits and vegetables } \\
\hline Prickly pear & $\begin{array}{l}\text { Opuntia ficus- } \\
\text { indica }\end{array}$ & $\begin{array}{l}\text { beles, } \\
\text { gelhi }\end{array}$ & beles & Fresh fruit \\
\hline Guava & Psidium sp. & zeitun & zeitun & Fresh fruit \\
\hline Bekuro lemon & Citrus sp. & $\begin{array}{l}\text { bekuro } \\
\text { lomin }\end{array}$ & $\begin{array}{l}\text { bekuro } \\
\text { lemon }\end{array}$ & Fresh fruit \\
\hline Banana & Musa sp. & muz & muz & Fresh fruit \\
\hline Mandarin & Citrus nobilis & manderini & manderini & Fresh fruit \\
\hline Peach & Prunus persica & kuk & kuk & Fresh fruit \\
\hline Onion & Allium spp. & shinkurti & shinkurt & Boiled and added to 'wot' \\
\hline Garlic & Allium sp. & $\begin{array}{l}\text { tsads } \\
\text { shinkurti }\end{array}$ & $\begin{array}{l}\text { nech } \\
\text { shinkurt }\end{array}$ & Boiled and added to 'wot' \\
\hline Tomato & $\begin{array}{l}\text { Lycopersicon } \\
\text { esculentum }\end{array}$ & pomidoro & timatim & Fresh vegetable; added to 'wot \\
\hline "Irish" potato & $\begin{array}{l}\text { Solanum } \\
\text { tuberosum }\end{array}$ & dinish & denich & Cooked and sliced for 'wot' \\
\hline Spinach beet & Beta cicla & kosta & kosta & $\begin{array}{l}\text { Boiled leaf, shredded and added to } \\
\text { 'wot' }\end{array}$ \\
\hline Cabbage & Brassica sp. & $\begin{array}{l}\text { tiklul- } \\
\text { hamli }\end{array}$ & tiklegomen & $\begin{array}{l}\text { Boiled leaf, shredded and added to } \\
\text { 'wot' }\end{array}$ \\
\hline Mustard & Brassica sp. & hamli & & $\begin{array}{l}\text { Boiled leaf, shredded and added to } \\
\text { 'wot' }\end{array}$ \\
\hline Miscellaneous & & & & \\
\hline
\end{tabular}




\begin{tabular}{|c|c|c|c|c|}
\hline Cotton & Gossypium sp. & tut & tut & $\begin{array}{l}\text { Local spinning and weaving as } \\
\text { cottage industry }\end{array}$ \\
\hline Coffee & Coffea arabica & bun & bunna & $\begin{array}{l}\text { Beans roasted and pounded for } \\
\text { drink }\end{array}$ \\
\hline Buckthorn & $\begin{array}{l}\text { Rhamnus } \\
\text { prinoides }\end{array}$ & gesho & gesho & $\begin{array}{l}\text { Pounded dried leaves and malted } \\
\text { barley for 'tella'; mixed with honey } \\
\text { to ferment 'tej' }\end{array}$ \\
\hline $\begin{array}{l}\text { (“Busy } \\
\text { Lizzie”) }\end{array}$ & $\begin{array}{l}\text { Impatiens } \\
\text { tinctoria }\end{array}$ & sasila & insosila & $\begin{array}{l}\text { Ground roots used as colouring } \\
\text { cosmetic }\end{array}$ \\
\hline Christthorn & $\begin{array}{l}\text { Ziziphus spina- } \\
\text { christi }\end{array}$ & gaba & & Raw berry eaten as fruit \\
\hline Soapberry & $\begin{array}{l}\text { Phytolacca } \\
\text { dodecandra }\end{array}$ & shebti & endod & $\begin{array}{l}\text { Pounded fruit capsule used as } \\
\text { washing soap }\end{array}$ \\
\hline $\begin{array}{l}\text { African } \\
\text { redwood }\end{array}$ & $\begin{array}{l}\text { Hagenia } \\
\text { abyssinica }\end{array}$ & habi & kosso & $\begin{array}{l}\text { Therapeutic for tapeworm } \\
\text { infestation }\end{array}$ \\
\hline Embelia & $\begin{array}{l}\text { Embelia } \\
\text { schimperi }\end{array}$ & enkoko & enkoko & $\begin{array}{l}\text { Therapeutic for tapeworm } \\
\text { infestation }\end{array}$ \\
\hline \multirow[t]{2}{*}{ (“Dock") } & $\begin{array}{l}\text { Rumex } \\
\text { abyssinicus }\end{array}$ & mekmoko & & $\begin{array}{l}\text { Red dye from roots used fas a } \\
\text { cosmetic: decoction of roots for a } \\
\text { drink }\end{array}$ \\
\hline & $? ?$ & kuni & & $\begin{array}{l}\text { Ground woody rhizomes used to } \\
\text { perfume hair }\end{array}$ \\
\hline
\end{tabular}

Note: $\quad$ phonetic spelling of Tigrinya and Amharic words is not definitive!

Source: Original Table from Vogt 1975, greatly expanded by the present Author

Table 2. Basic data for Tigray Region on number of households, area planted and yields of principal cereal, pulse and oil seed crops in meher season 2019/2020 


\begin{tabular}{|c|c|c|c|c|}
\hline Crop & $\begin{array}{l}\text { Households cultivating } \\
\text { (no) }\end{array}$ & $\begin{array}{l}\text { Area planted } \\
\text { (ha) }\end{array}$ & $\begin{array}{l}\text { Area per household } \\
\text { (ha) }\end{array}$ & $\begin{array}{l}\text { Yield per ha } \\
\text { (tonnes) }\end{array}$ \\
\hline \multicolumn{5}{|l|}{ Cereals } \\
\hline Tef & 633525 & 188392 & 0.297 & 1.655 \\
\hline Wheat $^{\mathrm{a}}$ & 386778 & 102258 & 0.264 & 2.190 \\
\hline Barley & 419786 & 85431 & 0.203 & 1.881 \\
\hline $\begin{array}{l}\text { Finger } \\
\text { millet }\end{array}$ & 369685 & 90199 & 0.243 & 2.392 \\
\hline Sorghum & 558917 & 232636 & 0.416 & 3.013 \\
\hline Maize & 835782 & 80151 & 0.095 & 3.075 \\
\hline \multicolumn{5}{|l|}{ Pulses } \\
\hline Field beans & 214391 & 11868 & 0.055 & 1.661 \\
\hline Field peas & 94466 & 7741 & 0.082 & 1.459 \\
\hline Chickpea & 35361 & 7566 & 0.214 & 1.561 \\
\hline Grass pea & 39081 & 7174 & 0.184 & 1.705 \\
\hline Lentil & 59064 & 6930 & 0.117 & 1.115 \\
\hline Fenugreek & 13199 & 603 & 0.046 & $?$ \\
\hline $\begin{array}{l}\text { Haricot } \\
\text { bean }^{b}\end{array}$ & 33903 & 3516 & 0.104 & 1.661 \\
\hline \multicolumn{5}{|l|}{ Oilseeds } \\
\hline Sesame & 145151 & 108291 & 0.746 & 0.749 \\
\hline Neug & 30675 & 5598 & 0.182 & 1.510 \\
\hline Linseed & 48592 & 4138 & 0.085 & 1.033 \\
\hline
\end{tabular}

Notes: a- three species combined

b- white variety only; red variety 1968 farmers growing but no other data

Source: $\quad$ adapted from CSA 2021

Figures 


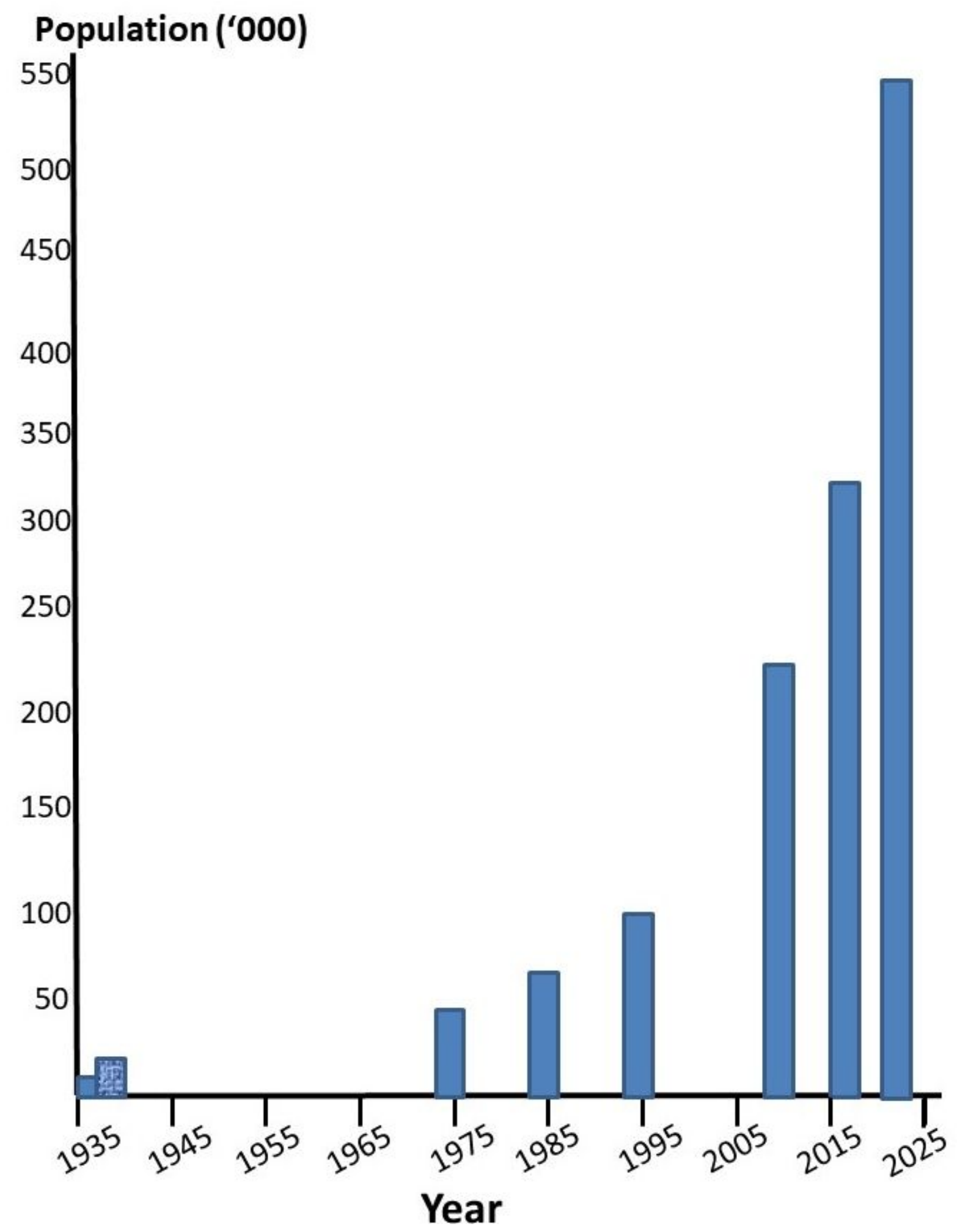

Figure 1

Human population growth of Mekelle, capital city of Tigray, 1935-2021 (Source: compiled from original data by the Author) 

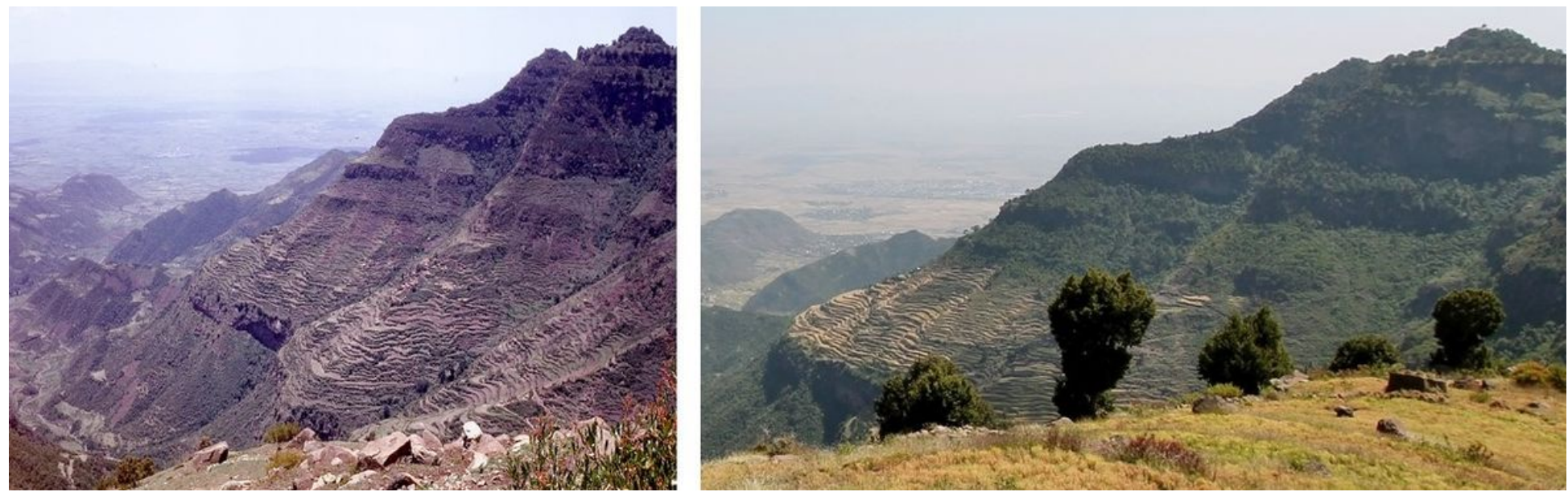

\section{Figure 2}

Cultivation on steep slopes at 3000 meters near Maychew; 18 June 1974 and 44 years later on 3 November 2018 (Source: both photos by the Author)

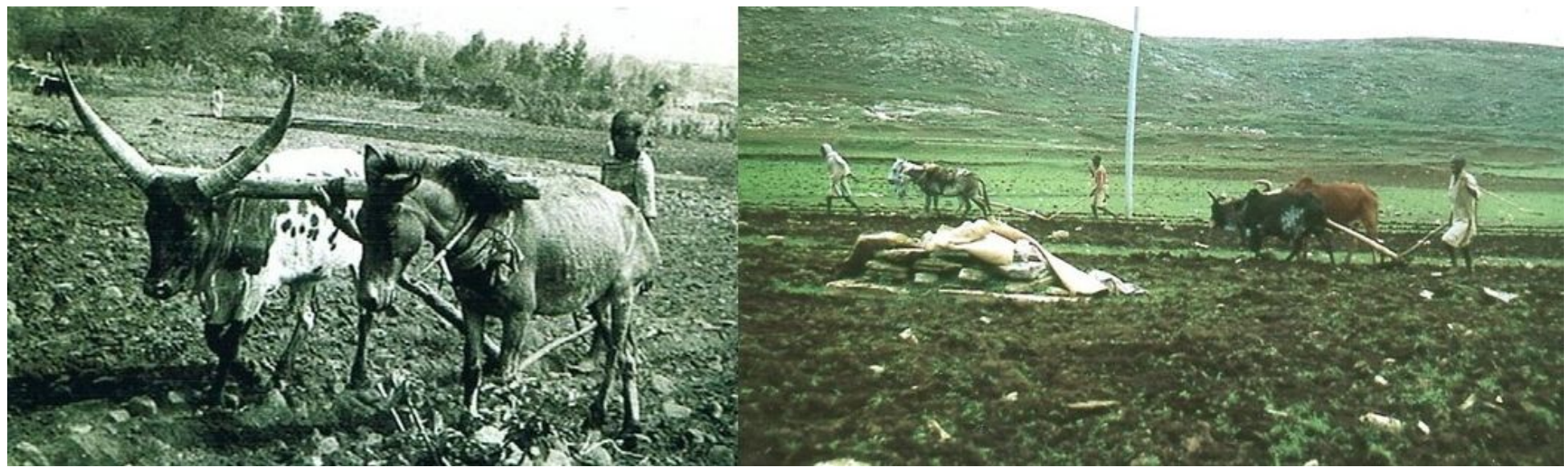

\section{Figure 3}

Abnormal use of animals for land preparation near highland Mekelle after drought-related livestock deaths (Ox in left hand picture is from Ethiopian lowlands and not highlands and note in right hand picture horse and mule having to be led) (Source: both photos by the Author taken in 1975) 


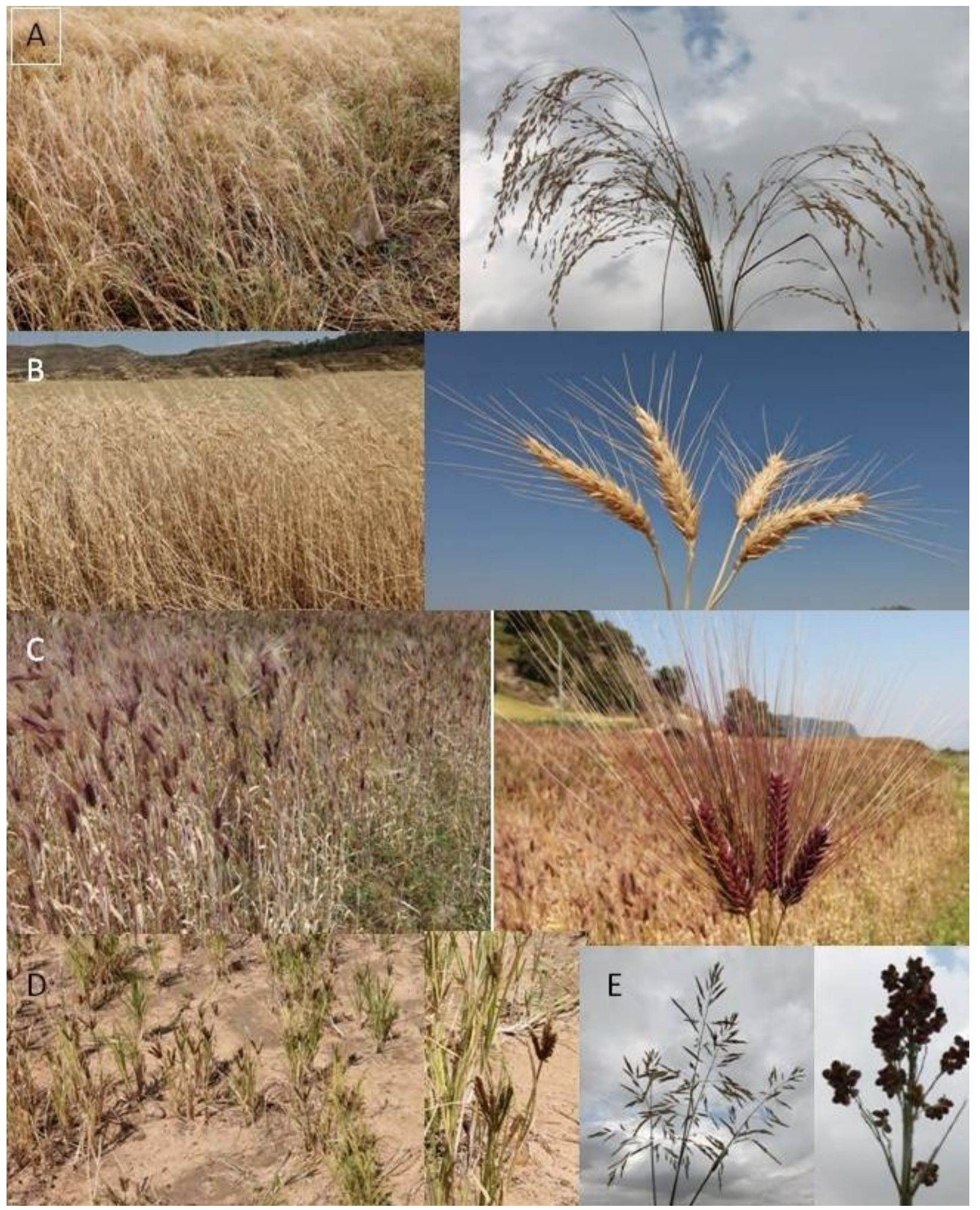

Figure 4

Cereal biodiversity in Tigray (A - Crop and ears of tef; B - Crop and ears of Emmer wheat; C - Crop and ears of barley (this variety for local beer); D - Finger millet crop and ears; $\mathrm{E}$ - Panicles of two of the three varieties of sorghum commonly grown) (Source: all photographs by the Author) 

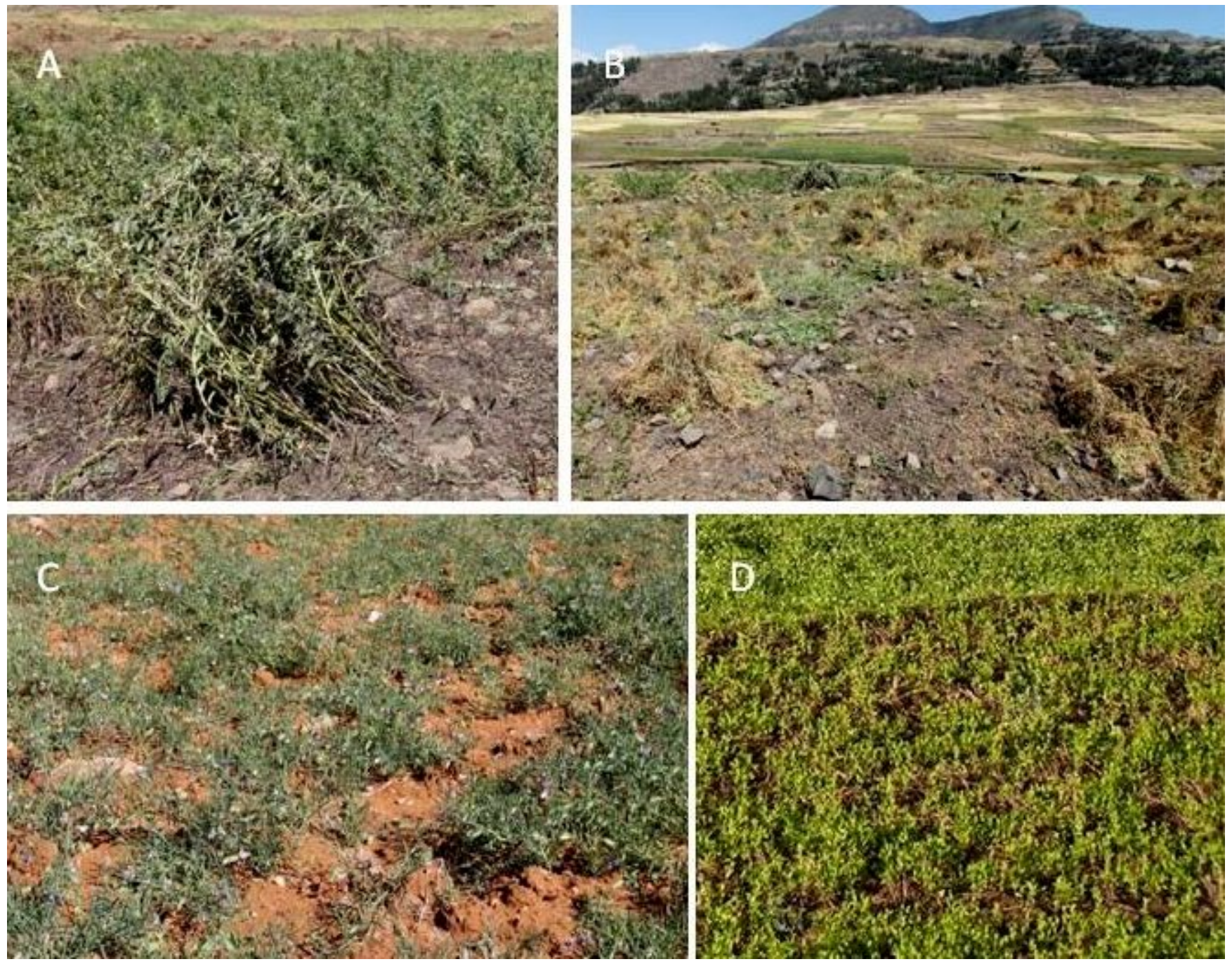

\section{Figure 5}

Pulse biodiversity in Tigray (A - Harvested and standing crop of field beans; B - Harvested lentils; C Growing grass pea; D - Growing chickpea) (Source: all photographs by the Author) 

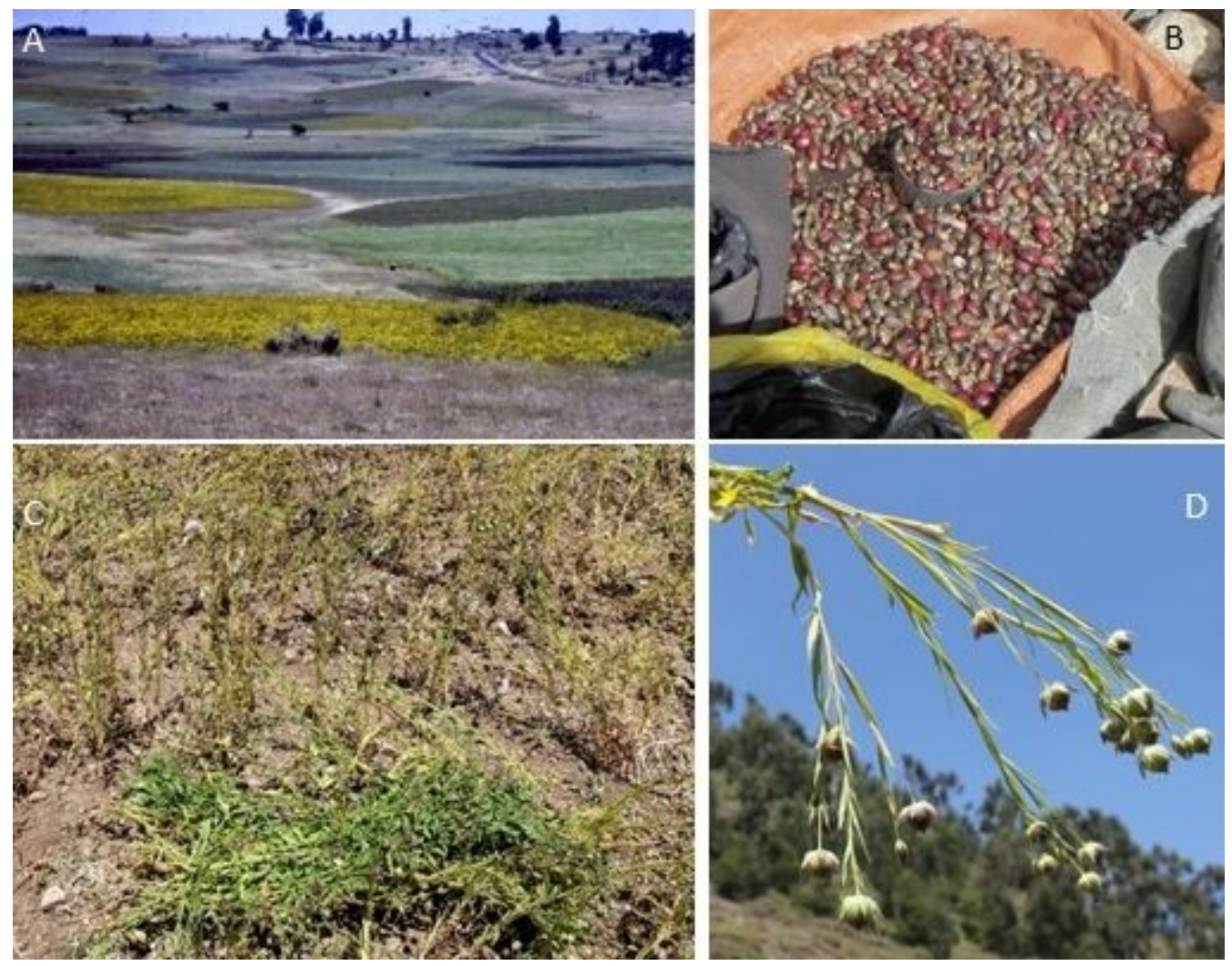

Figure 6

Oil seed biodiversity in Tigray (A - Neug (Niger Seed), Guizotia abyssinica ripening on black cotton soil; B Seeds of Castor Ricinis communis on sale at a local market; $C$ and D - Linseed Linum usitatissimum on shallow soil and seed head of almost ripe plant near Maychew, southern Tigray) (Source: all photographs by the Author) 

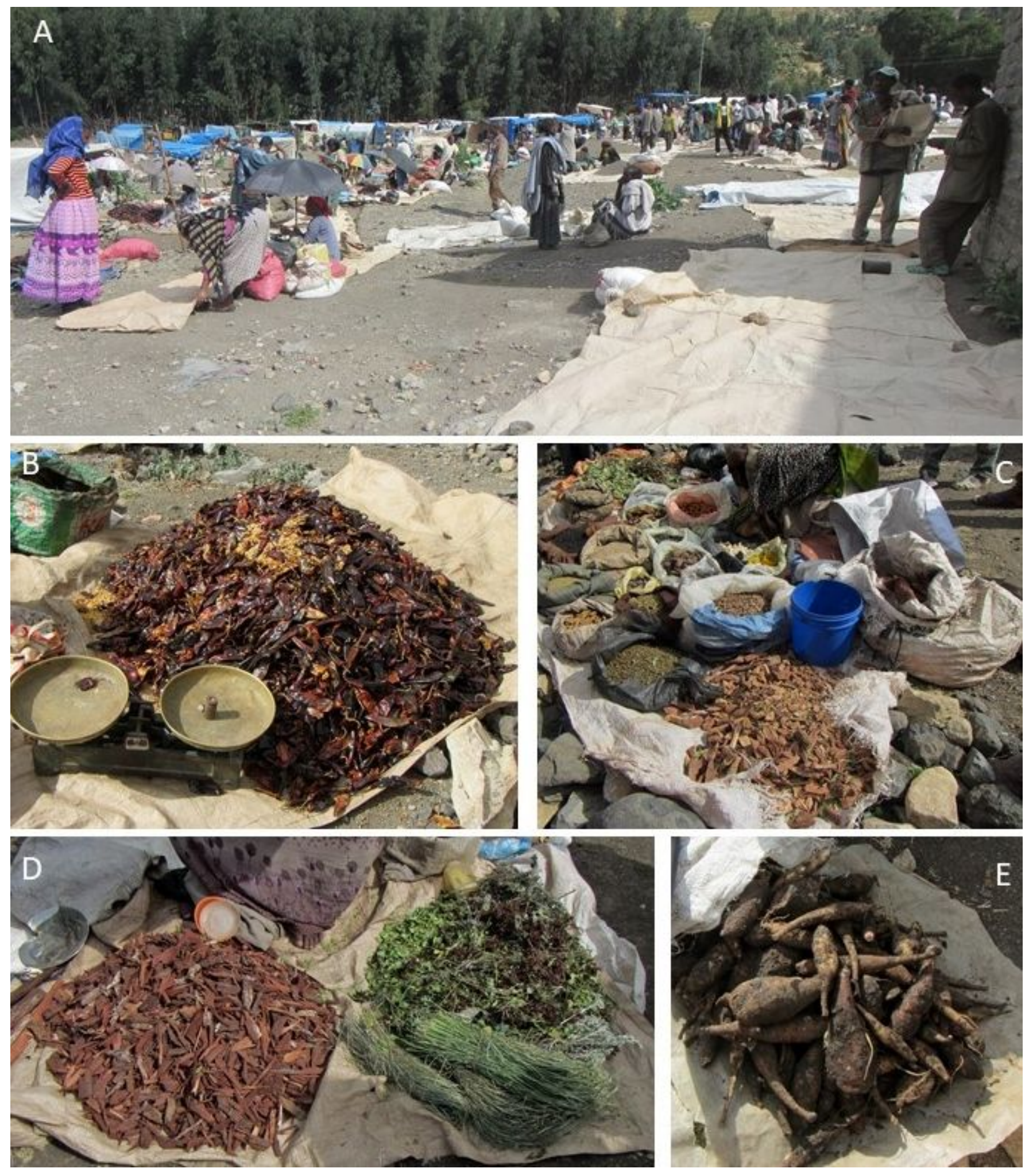

Figure 7

Miscellaneous crops (A - Local market, southern Tigray; B - Berbere seed cases on sale; C - various spices displayed for sale; $D$ - Bark chips of Juniperus procera for cooking and aromatic plants for perfuming of houses; E - Root tubers of Impatiens tinctoria for processing into a dye) (Source: all photographs by the Author at a local market near Debub, southern Tigray, November 3, 2018). 